\title{
The Effect of Fatigue on EMG Activity and Dynamic Balance of Subjects with Functional Lumbar Instability
}

\author{
Myong-Chul Kim, Ho-Sung Kim \\ Department of Physical Therapy, College of Health Science, Eulgi University, Seongnam, Korea
}

Purpose: The aim of the current study was to investigate EMG activity on dynamic balance of subjects with functional lumbar instability following fatigue of low back.

Methods: The subjects (24 university students) were divided into 2 groups; functional lumbar instability group (6 males and 6 females) and lumbar stable group ( 7 males and 5 females) who could complete a questionnaire and undergo a prone instability test. All participants were evaluated for distribution of muscle activity using the TeleMyo DTSTM system. Dynamic balance was tested by Y balance test. This study was conducted for measurement of EMG activity on dynamic balance with the difference between FLIG and control group following muscle fatigue.

Results: The functional lumbar instability group (FLIG) showed a significantly lower YBT score (\%) of anterior, posterolateral direction on Y-balance test (YBT) in dynamic balance than the lumbar stable group (LSG) $(p<0.05)$. The FLIG was significantly lower than the LSG in anterior direction in $\mathrm{EMG}$ activity $(\%)$ of $\mathrm{MF}, \mathrm{RA}, \mathrm{ES}, \mathrm{GMX}, \mathrm{GME}, \mathrm{RF}$, and posteromedial direction in $\mathrm{EMG}$ activity $(\%)$ of IO, ES and then posterolateral direction in $E M G$ activity $(\%)$ of $I 0, E S$ in dynamic balance $(p<0.05)$. There was significant correlation of $M F, R A$, and $G M X$ in anterior reach direction $(p<0.05)$ and $E S, G M E(p<0.01)$ and IO, ES in posteromedial reach direction $(p<0.05)$ and EO, ES, GMX in posterolateral reach direction $(\mathrm{p}<0.05)$ there was positive correlation.

Conclusion: This study showed that FLIG effected EMG activity by dynamic balance following muscle fatigue. Further study is needed for measurement of various ages and work with lumbar instability for clinical application.

Keywords: Functional lumbar instability, EMG activity, Muscle fatigue, Dynamic balance

\section{서 론}

요통은 일상생활에서 가장 많이 발생하는 근골격계 질환으로 신체 의 기능적인 문제를 초래한다. 또한 요통환자의 $70 \%$ 이상은 통증이 지속적으로 나타나 만성화로 이어지는데, ${ }^{2}$ 척추 주위 근육들의 약화 와 몸통 연부조직의 손상, 체간 근지구력의 감소, 척추원반의 퇴행성 변화 등으로 이어져 결국 허리뼈의 불안정성을 초래하게 된다. ${ }^{3}$ 이러 한 허리뼈 부위의 불안정성은 기계적(mechanical)과 기능적(functional) 불안정성으로 나뉜다. ${ }^{4}$ 기계적 불안정성은 방사선상(radiological) 앞굽힘-뒤굽힘 측면 방사선 사진에서 허리뼈가 $3 \mathrm{~mm}$ 이상 과전이 (hypermobility)된 객관적인 측정을 말하고, 기능적 불안정성은 임상 적으로 허리빼 분절 신경근 조절이 감소된 경우로써 요통의 재발, 휘 청거림의 느낌 등 주관적 측정을 의미한다.,5이 중 기능적 허리 불안

Received Jul 23, 2015 Revised Aug 11, 2015

Accepted Aug 16, 2015

Corresponding author Ho-Sung Kim

E-mail bhst0077@naver.com 정(functional lumbar instability, FLI)은 약 $40 \%$ 요통환자에서 나타나 는데 자세 조절 결함으로 인해 허리의 반복적인 불안정성과 휘청거 림을 경험하고, 허리의 위약감, 균형감각저하, 그리고 신경근조절의 약화로 만성요통을 초래한다. 허리 불안정은 허리뼈 기능장애를 일 으켜 초기 증상과 재발을 증가시키고, 몸통 구조물의 반복적인 손상 을 일으켜 시간이 경과함에 따라 척추 주위 근육의 면적 감소와 근위 축양상을 보여 요통을 더욱 악화시키게 된다. ${ }^{8}$ 또한 요통의 원인과 관 계없이 대부분 요통환자들은 근력의 감퇴와 지구력의 감소, 유연성 의 소실과 허리 및 다리관절운동범위가 제한된다. ${ }^{9}$ 이러한 허리 불 안정은 근피로에 의해서도 발생되는데 피로에 의한 운동조절능력 감 소는 고유수용감각과 관절운동성 저하를 초래하고, 근방추 역치증 가와 구심성 되먹임을 방해하여 관절자각도를 변화시킨다. ${ }^{10}$ 또한 Granacher 등'은 근피로에 의해 젖산이 축적되면 허리의 기능적 안정 Attribution Non-commercial License (Http:// creativecommons.org/license/by-nc/3.o.) which permits unrestricted non-commercial use, distribution, and reproduction in any medium, provided the original work is properly cited. 
성을 저하시켜 부상빈도가 증가한다고 하였고, Radebold 등르는 만성 요통시 허리근력저하와 몸통근육의 반응시간이 지연된다고 하였다.

한편 허리근육은 척추를 똑바로 세우는 동안 다리로 힘을 전달하 는 중요한 역할을 담당하고, ${ }^{3}$ 골반과 척추의 안정성유지는 근육 간 에 균형과 지구력, 근력에 의해 좌우된다.14,15 Johanson 등 ${ }^{16}$ 은 허리근 육피로가 체간에서 발목까지 고유수용성 감각에 영향을 준다고 하 였고, Bunn 등 16 은 운동 후 허리부척추근 피로(lumbar paraspinal fatigue)시 하지의 가자미근 운동신경원 활성도는 증가하나 넙다리네갈 래근과 안쪽넓은근 근활성도는 감소하여 자세균형에 영향을 미친다 고 하였다. 그러나 Jacobs 등18은 요통시 양측다리벌림근의 근력차이 는 있었지만 피로도와는 상관성이 없다고 하였고, Hodges와 Richard$\operatorname{son}^{19}$ 은 허리 기능적 불안정시 다리 근활성도와 균형 간에는 관련성 이 없다고 하였다. 또한 Davarian 등 20 은 허리 불안정성 만성요통환자 의 허리근육 근활성도와 지구력이 정상인과 큰 차이가 없다고 하였 고, Mazaheri 등른 요통환자가 서있는 자세에서 감각자극이 변화할 때 자세 흔들림에 큰 영향을 주지 않는다고 하였다. 이와 같이 기능적 허리 불안정성시 허리와 다리 근활성도 그리고 자세균형능력에 미치 는 영향에 대해서는 아직까지 명확하게 밝혀진 바가 없다. 따라서 본 연구는 기능적 허리 불안정성시 근피로도가 허리와 다리 근활성도 및 자세균형능력에 미치는 영향에 대해 알아봄으로써 향후 만성요 통시 재활치료의 기초자료를 제시하고자 하였다.

\section{연구방법}

\section{1. 연구대상}

본 연구대상은 $\mathrm{E}$ 대학교 재학생들 중 과거병력, 문진, 이학적 검사를 통해 기능적 허리 불안정으로 진단된 각 12 명의 기능적 허리불안정 집단(functional lumbar instability group)과 허리안정집단(lumbar stable group) 총 24 명을 대상으로 신장, 체중 및 연령 등을 고려해 각 집단에 무선배정하였다. 허리불안정군은 재발성 요통, 만성적인 요통 환자 중 최근 마지막 부상이 최소 3 개월 전 이었고, 검사 당시 완전한 체중 지지가 가능한 환자를 대상으로 하였나 검사 당시 수술을 받았거나 다리 불안정성이 있는 환자는 제외하였다. 모든 피험자들에게는 실 험 전 연구의 취지와 절차에 대해 충분히 설명하고, 자발적 동의를 얻 어 실험을 실시하였고, 실험대상자다리는 모두 우성(dominance)인 발 로 제한하였다.22 연구 대상자의 신체적 특성은 Table 1과 같다.

\section{2. 실험방법}

1) 기능적 허리 불안정 평가

기능적 허리 불안정은 엎드린 자세에서 불안정 검사(prone instability test, PIT)를 실시하였다. ${ }^{23}$ 대상자는 검사대에 엎드린 자세로 검사대
Table 1. General Characteristics of the Subjects

$N=24$

\begin{tabular}{lccc}
\hline Factors & LSG $(n=12)$ & FLIG $(n=12)$ & $p$-value \\
\hline sex & Male(6)/Female(6) & Male(7)/Female(5) & 0.30 \\
Age (year) & $20.1 \pm 0.5^{a}$ & $20.6 \pm 1.2$ & 0.20 \\
Height $(\mathrm{cm})$ & $170.5 \pm 2.2$ & $167.7 \pm 2.0$ & 0.30 \\
Weight $(\mathrm{kg})$ & $62.9 \pm 3.2$ & $60.9 \pm 2.6$ & 0.90 \\
\hline
\end{tabular}

${ }^{\mathrm{a} M e a n} \pm \mathrm{SD}$.

의 끝에 다리를 걸치고, 발은 바닥에 닿게 하였다. 검사자는 허리부위 옆에 서서 허리뼈의 각 극돌기 부위에 양손을 밀착하여 후방에서 전 방으로 통증이 없게 압박을 가하여 각 분절에서 통증이 발생한 것을 확인한 다음, 환자에게 바닥에서 발을 들고 다리를 몸통과 일직선이 되게 한 다음, 다시 이전과 같은 방법으로 압박을 적용하였다. 첫 번 째 자세에서 통증이 나타나고 두 번째 자세에서는 통증 증상이 나타 나지 않으면 양성으로 판정하고, 그 외는 음성으로 판정하였다.

2) 실험절차 및 방법

(1) 허리 근피로도

허리 근피로(muscle fatigue)유발을 위해 sørensen endurance test ( $a$ $=0.87$ 를 실시하였다. ${ }^{24}$ 실험 대상자를 검사대 위에 엎드린 자세로 취 하게 한 후 엉덩뼈능선을 검사대 끝에 위치하고 하체를 골반, 무릎, 발 목 3 부위를 끈(strap)으로 고정한 후 양팔을 겹쳐 가슴에 대고 상체를 수평으로 유지하며 등척성 수축을 실시하였는데 상체가 2 초 동안수 평면 아래로 $2 \mathrm{~cm}$ 감소시 근피로가 유발된 것으로 판정하였다.

\section{(2) 동적균형능력검사}

동적 균형능력(dynamic balance ability)을 검사하기 위하여 Y-balance test $(\mathrm{YBT})(\alpha=0.85 \times 0.91)$ 를 실시하였다. ${ }^{25} \mathrm{YBT}$ 검사는 $120^{\circ}$ 간격으로 앞측(anterior), 뒤내측(posteriomedial), 뒤외측(posteriolateral) 3 개의 선 이 그려진 중앙에서 환자는 한 다리로 서서 반대쪽 발로 각 방향의 선을 따라서 최대한 멀리 뻗은 거리를 기록하는 평가방법이다. 측정 값은 환자가 뻗은 지점까지의 거리 $(\mathrm{cm})$ 를 다리 길이 $(\mathrm{cm})$ 로 나눈 백분 율을 산출하였고, 각 자세마다 2번씩 측정하여 평균값을 기록하였 다. 또한 동적 균형시 근활성도를 평가하기 위해서 근전도분석을 동 시에 실시하였다(Figure 1).

\section{(3) 근활성도검사}

본 연구에서 동적 균형검사시 각 근육의 근활성도(electromyographic activity)는 무선 $\mathrm{EMG}$ 인 TeleMyoDTS ${ }^{\mathrm{TM}}$ 로 측정하였다. ${ }^{26}$ 근전도계와 무선으로 연결된 컴퓨터에서 각각의 연결된 근육에 해당하는 채널 을 지정하여 근전도 신호를 관찰하였고, 근전도 측정단위는 $\mu \mathrm{V}$ 로 기 록하였다.2728 


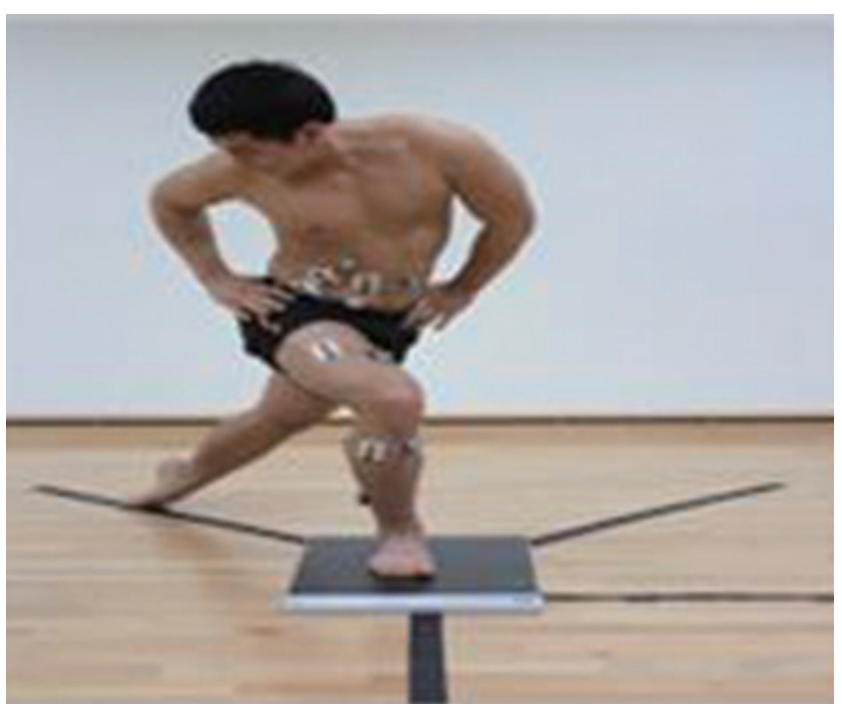

Figure 1. EMG activity with $Y$ balance test.

\section{(4) 근전도 전극부착}

전극의 부착부위는 동일한 실험자에 의해 실시하였고, 자발적 수축 으로 강한 등척성수축시 보이는 근힘살부위에 부착하였다. 실험 1 회 당 전체 근수축 시간을 20 초로 하고, 실험시간 간격은 근수축의 선행 효과를 감소시키기 위해 근수축 후 10 초간의 자료를 선택하고. 각 실 험사이에는 30 초의 휴식을 주었다. ${ }^{25}$

\section{(1) 허리 근전도 측정}

허리근육 근활성도를 측정하기 위해 뭇갈래근(multifidus, MP)은 L5 극 돌기로 부터 외측으로 $3 \mathrm{~cm}$ 떨어진 곳, 배속빗근(internal oblique, $\mathrm{IO})$ 은 배꼽선과 위앞엉덩이벼가시의 중간, 배바깥빗근(external oblique, EO)은 배꼽에서 가쪽 $15 \mathrm{~cm}$ 지점, 배곧은근(rectus abdominis, $\mathrm{RA}$ )은 배꼽 위 $5 \mathrm{~cm}$ 지점, 척추세움근(erector spinae, ES)은 L2에서 양 쪽으로 $2 \mathrm{~cm}$ 떨어진 곳에 전극을 부착하였다. ${ }^{25,26}$

\section{(2) 다리 근전도 측정}

다리 근활성도를 측정하기 위해 큰볼기근(gluteus maximus, GMX), 중간볼기근(gluteus medius, $\mathrm{GME}$ ), 앞정강근(tibialis anterior, TA), 긴종 아리근(peroneus longus, PL), 넙다리곧은근(rectus femoris, RF), 넙다리 두갈래근(biceps femoris, $\mathrm{BF}$ )은 근팽배부 지점에서 $2 \mathrm{~cm}$ 떨어진 부위 에 전극을 부착하였다. 참고전극(reference electrode)은 활동전극의 원 위부 $2 \mathrm{~cm}$ 에 부착하였다.13,25

\section{(5) 표면근전도 신호 및 분석}

몸통 운동과 자세유지에 작용하는 허리와 하지의 근활성도를 측정 하기 위해서 12 개의 DE-3.1 표면전극과 1 개의 접지전극 TeleMyo DT-
STM 를 사용 하였다. 또한 12 개 채널의 표면 근전도 아날로그 신호와 EMG sensor에서 디지털 신호는 Acqknowledge 3.7.2 (BIOPAC System Inc. Santa Barbara, USA, 2010) 소프트웨어를 이용하여 자료처리 하였 다. 신호의 표본추출률(sampling rate)은 $1,024 \mathrm{~Hz}$ 로 설정하고, 주파수 대역폭(band width)은 $10 \mathrm{~Hz}$ 노치 필터(notch filter)를 사용하였다. 수 집된 신호는 완파 정류(full-wave rectification)한 후 root mean square (RMS) 처리하였다. 또한 근전도 잡음(noise)을 제거하기 위해서 소음 제거율(common mode rejection ratio)을 $100 \mathrm{~dB}$ 이상으로 설정하였다. 표면 $\mathrm{EMG}$ 전극을 붙이는 근육위치와 각 개인의 근활성도 차이로 인 해 생기는 근활성도의 오차를 최대한 줄이기 위해 $50 \mathrm{~ms}$ 이상에서 정 류된 평균 근전도(average peak EMG $(\mu \mathrm{V})$ )값을 대표값으로 하고, 그것 을 표준근전도(normalized peak EMG (\%)) 값으로 환산해서 자료분석 에 이용하였다.

\section{3. 자료 분석}

본 연구의 모든 자료는 Window용 SPSS/PC 21.0 통계프로그램을 이용 하여 기술 통계치 (평균, 표준편차)를 산출하고, 허리안정집단과 허리 불안정집단간의 허리 근피로도 유발 후 동적 균형에 따른 근활성도 차이를 보기위해 짝비교 $\mathrm{t}$ 검정(paired samples t-test)을 실시하였고, 두 집단간 근활성도 차이를 보기위해 독립표본 $\mathrm{t}$ 검정(Independent samples t-test)을 실시하였다. 또한 두 집단에서 동적균형능력과 근활성도 간의 상관관계를 검증하기 위해 pearson's correlation을 산출하였다. 모든 변인에 대한 통계적 유의수준은 $\alpha=0.05$ 로 설정하였다.

\section{결 과}

\section{1. 두 집단에서 근피로 전후 동적균형시 YBT Score}

근피로 전후 동적균형을 측정하기 위해 YBT를 실시한 결과 YBT score (\%)는 근피로 후 허리불안정집단은 앞측(anterior), 뒤외측(posterolater$\mathrm{al})$ 에서 허리안정집단보다 유의하게 낮았다 $(\mathrm{p}<0.05)$. 그러나 뒤내측 (posteromedial)은 허리불안정집단이 안정집단보다 감소된 경향은 있 으나 통계적으로 유의하지 않았다. 두 집단간 근피로 후 YBT score (\%) 는 앞측(anterior), 뒤외측(posterolateral)에서 허리불안정집단이 안정 집단보다 유의하게 낮았다 $(\mathrm{p}<0.05)$ (Table 2).

\section{2. 허리 안정집단에서 근피로 전후 동적균형시 근활성도}

허리 안정집단에서 근피로 전후 3 방향에 대한 동적균형시 근활성도 의 결과 앞측(Anterior)에서는 배곧은근(RA), 척추세움근(ES), 큰볼기 근(GMX), 중간볼기근 $(\mathrm{GME})$ 의 근활성도는 약간 감소된 경향은 있으 나 통계적으로 유의하지 않았다(Table 3). 


\section{3. 허리 불안정집단에서 근피로 전후 동적균형시 근활성도}

허리 불안정집단에서 근피로 전후 3 방향에 대한 동적균형시 근활성

Table 2. The YBT score with dynamic balance following muscle fatigue

\begin{tabular}{llccc}
\hline \multirow{2}{*}{ Direction } & & \multicolumn{3}{c}{ YBT score $(\%)^{\mathrm{b}}$} \\
\cline { 3 - 5 } & & \multicolumn{1}{c}{ LSG } & FLIG & $\mathrm{t}$ \\
\hline Anterior & Pre & $90.30 \pm 2.10^{\mathrm{a}}$ & $82.60 \pm 3.20$ & 1.70 \\
& Post & $75.30 \pm 3.30$ & $62.60 \pm 2.80^{*}$ & $2.30^{+}$ \\
\multirow{2}{*}{ Posteromedial } & Pre & $81.30 \pm 3.20$ & $73.90 \pm 2.70$ & 1.90 \\
& Post & $78.30 \pm 2.70$ & $70.60 \pm 3.50$ & 2.20 \\
Posterolateral & Pre & $95.90 \pm 4.00$ & $87.90 \pm 2.30$ & 1.80 \\
& Post & $80.30 \pm 2.70$ & $67.60 \pm 3.60 *$ & $3.70^{+}$ \\
\hline
\end{tabular}

${ }^{a}$ Mean \pm SD. ${ }^{+} p<0.05$ between LSG and FLIG; ${ }^{*} p<0.05$ between Pre and Post. LSG, lumbar stable group; FLIG, Functional lumbar instability group; Pre, pre-fa-

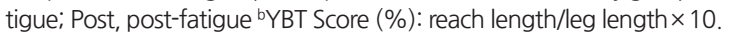

도의 결과 앞측(Anterior)에서는 뭇갈래근(MF), 배곧은근(RA), 척추 세움근(ES), 큰볼기근(GMX), 중간볼기근(GME), 넙다리곧은근(RF), 뒤내측(posteromedial)에서는 배속빗근( $\mathrm{IO})$, 척추세움근(ES), 큰볼기 근(GMX), 그리고 뒤외측(posterolateral)에서는 배바깥빗근(EO), 척추 세움근(ES), 큰볼기근(GMX)의 근활성도가 허리 불안정집단이 안정 집단보다 유의하게 낮았다 $(\mathrm{p}<0.05)$ (Table 3).

\section{4. 두 집단에서 근피로 전후 동적균형시 근활성도}

두 집단간 근활성도는 앞측(Anterior)에서는 뭇갈래근(MF), 배곧은근 (RA), 척추세움근(ES), 중간볼기근(GME), 넙다리곧은근(RF) 뒤내측 (posteromedial)에서는 배속빗근(IO), 척추세움근(ES), 그리고 뒤외측 (posterolateral)에서는 배바깥빗근(EO), 척추세움근(ES)의 근활성도가 허리 불안정집단이 안정집단보다 유의하게 낮았다 $(\mathrm{p}<0.05)$ (Table 3).

Table 3. The EMG activity with dynamic balance following muscle fatigue

\begin{tabular}{|c|c|c|c|c|c|c|c|c|c|c|}
\hline \multirow{3}{*}{ Muscles } & & \multicolumn{9}{|c|}{ Normalized Peak EMG activity $(\%)^{b}$} \\
\hline & & \multicolumn{3}{|c|}{ Anterior } & \multicolumn{3}{|c|}{ Posteromedial } & \multicolumn{3}{|c|}{ Posterolatetal } \\
\hline & & LSG & FLIG & $\mathrm{t}$ & LSG & FLIG & $\mathrm{t}$ & LSG & FLIG & $t$ \\
\hline \multirow[t]{2}{*}{ GMX } & Pre & $8.40 \pm 2.50^{a}$ & $8.10 \pm 2.80$ & 1.90 & $8.60 \pm 2.60$ & $8.10 \pm 2.80$ & 1.80 & $11.90 \pm 1.30$ & $11.10 \pm 1.90$ & 0.80 \\
\hline & Post & $7.70 \pm 1.60$ & $6.10 \pm 1.90^{*}$ & $1.60^{+}$ & $7.20 \pm 1.30$ & $5.60 \pm 1.50^{*}$ & $2.10^{+}$ & $10.20 \pm 2.80$ & $8.50 \pm 2.50^{*}$ & $1.60^{+}$ \\
\hline \multirow{2}{*}{ GME } & Pre & $8.90 \pm 3.10$ & $8.50 \pm 3.80$ & 1.00 & $8.10 \pm 1.70$ & $7.90 \pm 2.40$ & 0.50 & $10.80 \pm 3.10$ & $9.50 \pm 3.90$ & 1.20 \\
\hline & Post & $8.10 \pm 1.50$ & $6.30 \pm 1.10^{*}$ & $1.20^{+}$ & $7.40 \pm 0.50$ & $7.60 \pm 1.20$ & 1.50 & $10.00 \pm 2.70$ & $8.00 \pm 2.30 *$ & 2.30 \\
\hline \multirow[t]{2}{*}{ RF } & Pre & $8.10 \pm 1.70$ & $7.60 \pm 0.80$ & 1.90 & $6.60 \pm 0.70$ & $6.10 \pm 0.70$ & 1.40 & $6.60 \pm 3.30$ & $6.30 \pm 2.70$ & 1.70 \\
\hline & Post & $7.70 \pm 3.20$ & $5.60 \pm 0.40 *$ & $1.50^{+}$ & $6.20 \pm 2.60$ & $6.20 \pm 2.30$ & 0.40 & $6.20 \pm 0.80$ & $5.80 \pm 1.30$ & 0.30 \\
\hline \multirow[t]{2}{*}{ BF } & Pre & $7.50 \pm 1.50$ & $6.80 \pm 1.10$ & 0.70 & $6.20 \pm 1.50$ & $6.20 \pm 1.50$ & 2.10 & $11.90 \pm 2.40$ & $11.30 \pm 2.90$ & 2.10 \\
\hline & Post & $7.10 \pm 2.60$ & $6.60 \pm 3.20$ & 2.80 & $6.10 \pm 3.90$ & $6.10 \pm 3.70$ & 0.80 & $11.20 \pm 3.10$ & $10.90 \pm 3.60$ & 3.10 \\
\hline \multirow[t]{2}{*}{ MF } & Pre & $10.70 \pm 1.30$ & $8.50 \pm 1.50$ & 1.40 & $10.90 \pm 1.80$ & $9.30 \pm 2.10$ & 2.30 & $9.50 \pm 1.90$ & $8.30 \pm 1.70$ & 1.30 \\
\hline & Post & $9.10 \pm 1.00$ & $6.50 \pm 3.20 *$ & $1.00^{+}$ & $9.20 \pm 0.40$ & $7.40 \pm 1.70$ & 3.60 & $8.40 \pm 1.20$ & $7.90 \pm 1.20$ & 3.50 \\
\hline \multirow[t]{2}{*}{10} & Pre & $4.60 \pm 2.70$ & $4.50 \pm 1.80$ & 1.00 & $7.80 \pm 2.10$ & $6.20 \pm 2.80$ & 1.70 & $5.00 \pm 1.30$ & $4.70 \pm 0.60$ & 1.80 \\
\hline & Post & $4.60 \pm 3.30$ & $4.10 \pm 2.40$ & 1.80 & $5.10 \pm 2.80$ & $3.30 \pm 2.50^{*}$ & $2.10^{+}$ & $4.90 \pm 1.20$ & $4.80 \pm 1.60$ & 1.90 \\
\hline \multirow[t]{2}{*}{ EO } & Pre & $6.10 \pm 1.90$ & $6.70 \pm 1.20$ & 0.80 & $5.60 \pm 3.20$ & $4.70 \pm 3.20$ & 1.80 & $4.70 \pm 2.60$ & $3.50 \pm 2.40$ & 2.70 \\
\hline & Post & $5.50 \pm 2.30$ & $5.10 \pm 0.50$ & 0.40 & $5.10 \pm 2.50$ & $3.60 \pm 1.10$ & 0.90 & $3.90 \pm 2.40$ & $2.10 \pm 2.30 *$ & $1.60^{+}$ \\
\hline \multirow[t]{2}{*}{ RA } & Pre & $11.50 \pm 2.60$ & $10.80 \pm 2.90$ & 1.60 & $10.40 \pm 2.30$ & $10.10 \pm 0.30$ & 3.60 & $10.50 \pm 3.20$ & $9.50 \pm 3.10$ & 1.60 \\
\hline & Post & $10.90 \pm 3.50$ & $9.10 \pm 3.10 *$ & 1.90 & $9.60 \pm 3.20$ & $8.60 \pm 3.80$ & 2.00 & $9.40 \pm 2.30$ & $8.10 \pm 2.90$ & 2.10 \\
\hline \multirow[t]{2}{*}{ ES } & Pre & $12.80 \pm 0.50$ & $11.30 \pm 1.40$ & 1.50 & $10.90 \pm 2.70$ & $8.90 \pm 2.10$ & 2.50 & $10.40 \pm 2.50$ & $9.80 \pm 1.10$ & 2.70 \\
\hline & Post & $12.10 \pm 4.20$ & $8.20 \pm 3.20 *$ & $2.60^{+}$ & $9.10 \pm 4.80$ & $7.40 \pm 3.80 *$ & $2.60^{+}$ & $9.20 \pm 2.90$ & $7.20 \pm 3.70 *$ & $3.60^{+}$ \\
\hline
\end{tabular}

${ }^{\mathrm{a} M e a n} \pm \mathrm{SD}$. ${ }^{\dagger} \mathrm{p}<0.05$ between LSG and FLIG; * $\mathrm{p}<0.05$ between Pre and Pos; ${ }^{\mathrm{b}}$ EMG activity, Electromyographic activity.

LSG, lumbar stable group; FLIG, Functional lumbar instability group; Pre, pre-fatigue; Post, post-fatigue; GMX, gluteus maximus; GME, gluteus medius; RF, rectus femoris; $B F$, biceps femoris; MF, multifidus; IO, internal oblique; EO, external oblique; $R A$, rectus abdominis; ES, erector spinae.

Table 4. The correlation between YBT score and EMG activity following muscle fatigue

\begin{tabular}{lcccccccc}
\hline \multirow{2}{*}{ YBT score $^{\mathrm{b}}(\%)$} & \multicolumn{7}{c}{ Normalized Peak EMG activity $(\%)$} \\
\cline { 2 - 8 } & MF & IO & EO & RA & ES & GMX & GME & RF \\
\hline Anterior & $0.69^{*}$ & & & $0.45^{*}$ & $0.82^{* *}$ & $0.76^{*}$ & $0.26^{* *}$ \\
Posteromedial & & $0.32 *$ & & & $0.57^{*}$ & & & \\
Posterolateral & & & $0.28^{*}$ & & $0.61^{*}$ & & $0.53^{*}$ &
\end{tabular}

${ }^{*} \mathrm{p}<0.05 ;{ }^{* *} \mathrm{p}<0.01$; $\mathrm{E} \mathrm{EMG}$ activity, Electromyographic activity; ${ }^{\mathrm{b} Y B T}$, Y-balance test.

MF, multifidus; IO, internal oblique; EO, external oblique; RA, rectus abdominis; ES, erector spinae; GMX, gluteus maximus; GME, gluteus medius; RF, rectus femoris; BF, biceps femoris. 


\section{5. 근피로 후 YBT score와 근활성도 간의 상관관계}

동적균형시 YBT score와 근활성도 간의 상관관계는 앞측(anterior)과 뭇갈래근(MF), 배곧은근(RA), 척추세움근(ES), 큰볼기근(GMX), 중 간볼기근(GME) 간에는 $\mathrm{p}<0.05$ 유의수준에서, 척추세움근(ES), 중간 볼기근(GME) 간에는 $\mathrm{p}<0.01$ 유의수준에서 정상관관계를 보였다. 그 리고 뒤내측(posteromedial)과 배속빗근(IO), 척추세움근(ES) 간에는 $\mathrm{p}<0.05$ 유의수준에서, 뒤외측(posterolateral)과 배바깥빗근(EO), 척추 세움근(ES), 큰볼기근(GMX) 간에는 $\mathrm{p}<0.05$ 유의수준에서 정상관관 계를 보였다(Table 4).

\section{고 찰}

신체 균형은 근피로시 중추 기전에서 신경근 조절결함이 나타나 장 시간 자세동요가 발생하고, ${ }^{28}$ 고유수용성감각 결함과 동적움직임제 한, 자세조절감각 저하, 근동원시간의 지연, 그리고 하지 정렬의 이상 등 29,30 이 유발되어 기능적 허리 불안정성으로 진행된다. 본 연구에서 허리 근피로 유발 후 YBT로 동적균형검사를 실시한 결과 YBT score (\%)는 허리 불안정집단에서는 앞측(anterior), 뒤외측(posterolateral)에 서 유의한 감소를 보여 허리 불안정집단에서 동적균형수행능력이 저 하되었다(Table 2). 이 결과는 허리근육 피로 후 불안정한 표면에서 서 있을 때 뒤로 흔들림(postural sway)이 나타나고, ${ }^{31}$ 허리폄근 피로 후 정 적자세에서 무게중심이 앞뒤방향으로 흔들림이 나타났다고 보고한 연구 ${ }^{32,33}$ 와 마찬가지로 본 연구에서도 허리 근피로로 인해 신경근조 절능력 부전으로 앞측과 뒤외측방향으로 균형능력이 저하된 것으 로 보인다.

근피로 후 동적균형시 근활성도는 앞측에서는 뭇갈래근(MF), 배 곧은근(RA), 척추세움근(ES), 큰볼기근(GMX), 중간볼기근(GME), 넙 다리곧은근(RF)의 근활성도가 허리 불안정집단이 안정집단보다 유 의하게 낮았다(Table 3). 이는 허리 불안정집단이 안정집단에 비해 자 세제어기능이 저하된 것으로 보인다. Kankaanpää 등 ${ }^{34}$ 은 허리 불안정 시 동적자세 균형에서 체성감각의 역할이 크며 척추세움근(ES)과 뭇 갈래근(MF)은 척추 폄근으로써 요부굴곡을 제어하는 역할을 한다 고 하였다. Ebenbichler 등 35 은 요통환자들이 폄동작이 잘 안되는 것 은 고유수용성감각 저하를 의미하며, 결국 척추에 불안정성을 초래 한다고 하였고, Granacher 등"은 척추세움근(ES)은 원심성 굽힘을 통 해 허리뼈의 굽힘을 조절하는데 중추신경계로 고유수용성자극의 정 보를 지속으로 보내는 역할을 한다고 하였다. 본 연구에서도 체중이 앞으로 이동시 활성화되는 척추세움근(ES)과 뭇갈래근(MF)이 약화 되는데(Table 3), 이는 동적균형시 척추폄근인 척추세움근(ES)이 감속 역할을 하는데 ${ }^{35}$ 폄근의 감속기능이 원활히 작용하지 않은 것으로 보 인다. 또한 뭇갈래근(MF)은 몸통과 허리에서 불필요한 움직임을 예
방하고 사지가 움직일 수 있는 안정적인 척추를 만들어 주는데, ${ }^{34,35}$ 본 연구에서도 근피로시 뭇갈래근(MF) 활성도가 감소되고 허리자세 감각 부전으로 인한 미리먹임(feed forward)기능이 약화된 것으로 보 인다. 허리 불안정집단에서 체중이 앞으로 이동시 큰볼기근(GMX)과 중간볼기근(GME)의 근활성도가 감소되었는데(Table 3) 이는 만성요 통시 볼기근의 근피로가 유의하게 증가되어 몸통균형에 영향을 준다 고 한다. Kankaanpää 등 ${ }^{34}$ 은 연구와 볼기근 운동이 허리 불안정성 만 성요통환자의 요부안정성 증진에 영향을 미친다고 보고한 Lee 등 ${ }^{36}$ 의 연구와 마찬가지로 하지 안정화 근육인 뭇갈래근(MF)과 척추세움 근(ES) 약화로 인해 이들 근육 작용에도 영향을 미친 것으로 보인다. 또한 뒤내측으로 이동시 배속빗근(IO), 척추세움근(ES), 큰볼기근 (GMX)의 근활성도가 허리 불안정집단이 안정집단보다 유의하게 낮 게 나타났고, 뒤외측으로 이동시 외복사근(EO), 척추세움근(ES), 큰 볼기근(GMX)의 근활성도가 허리 불안정집단이 안정집단보다 유의 하게 낮게 나타났다(Table 3). 이는 배속빗근(IO)과 배바깥빗근(EO) 은 주로 자세 유지근인 안정성협력근(stability synergists)으로, ${ }^{34,37}$ 본 연구에서도 허리불안정시 뒤내·외측으로 움직일시 허리 안정근인 배속빗근 $(\mathrm{IO})$ 과 배바깥빗근 $(\mathrm{EO})$ 그리고 척추세움근 $(\mathrm{ES})$ 과 큰볼기근 (GMX)의 약화가 동적균형에 영향을 미친 것으로 보인다.

동적균형과 근활성도간의 상관관계를 보면 앞측에서는 뭇갈래근 (MF), 배곧은근(RA), 척추세움근( $\mathrm{ES})$, 큰볼기근 $(\mathrm{GMX})$, 중간볼기근 (GME)이 작용에 영향을 미치며 앞내측은 배속빗근(IO), 척추세움근 (ES) 그리고 뒤외측에서는 배바깥빗근 $(\mathrm{EO})$, 척추세움근( $\mathrm{ES})$, 큰볼기근 (GMX)에 영향을 주었다(Table 4). Lee 등36은 요통환자와 정상인의 허 리굽힘근과 폄근을 비교시 허리굽힘근력에는 유의한 차이가 없으나 폄근력의 경우 요통 환자들이 매우 위약하다고 하였고, Johanson 등 32 은 허리폄근의 위약은 근력과 근지구력에 영향을 주어 결국 허리 불 안정성의 원인이 될 수 있다고 하였다. 본 연구에서도 요통환자가 근피 로 후 각 방향에 따른 허리폄 근육의 고유수용성감각 결함으로 척추 분절에 불안정성을 초래해 동적균형감각이 저하된 것으로 보인다.

본 연구에서 근피로에 의한 기능적 허리불안정시 허리폄근인 척추 세움근과 뭇갈래근의 약화로 인해 안정화근육인 큰볼기근과 중간 볼기근의 작용에 영향을 준 것으로 보인다.38 이는 안정성 근육과 운 동성 근육사이의 동원 순서와 근길이에 대한 불균형으로 인해 허리 불안정성이 나타나기 때문으로, ${ }^{30,39}$ 기능적 허리 불안정시 동적균형 능력은 각 방향에 따라 나타나는 근육의 근활성도에따른 체성감각 에 영향을 받는 것으로 보인다. 따라서 기능적 허리 불안정시 동적 균 형자세에 따라 관여하는 근육의 분석을 통해 각 방향에 따라 허리 안정화에 기여하는 근육을 강화하고, 미리먹임 운동조절을 활성시 켜 허리재손상을 예방할 수 있을 것으로 사료된다.

본 연구의 제한점은 적은 피험자를 대상으로 실험을 했고, 근력 측 
정시 각 개인의 근활성도 차이, 그리고 허리와 다리근육을 구성하는 근섬유 조성의 차이로 인해 생기는 근활성도의 오차를 객관화 하기 에 어려움이 있었다. 향후, 기능적 허리불안정이 있는 남녀간 비교, 다 양한 연령대를 대상으로 근활성도 차이를 객관화, 척도화 시키는 연 구가 이루어져야 할 것으로 사료된다.

\section{REFERENCES}

1. Hoy D, Bain C, Williams G et al. A systematic review of the global prevalence of low back pain. Arthritis Rheum. 2012;64(6):2028-37.

2. Fritz JM, Cleland JA, Speckman M et al. Physical therapy for acute low back pain: Associations with subsequent healthcare costs. Spine. 2008; 33(16):1800-5

3. Adams MA, Roughley PJ. What is intervertebral disc degeneration, and what causes it?. Spine.2006;31(18):2151-61.

4. Bram J, Zanetti M, Min K et al. MR abnormalities of the intervertebral disks and adjacent bone marrow as predictors of segmental instability of the lumbar spine. Acta Radiol. 1998;39(1):18-23.

5. Cook C, Brismee JM, Sizer Jr PS. Subjective and objective descriptors of clinical lumbar spine instability. Delphi study. Man Ther. 2006;11(1):1121.

6. Demoulin C, Distrée V, Tomasella M et al. Ann Readapt Lumbar functional instability: a critical appraisal of the literature. Med Phys. 2007; 50(8):677-84.

7. Panjabi MM. Clinical spinal instability and low back pain. J Electromyogr Kinesiol. 2003;13(4):371-9.

8. Koumantakis GA, Winstanley J, Oldham JA. Thoracolumbar proprioception in individuals with and without low back pain: intratester reliability, clinical applicability, and validity. J Orthop Sports Phys Ther. 2002;32(7):327-35.

9. Wong TK, Lee RY. Effects of low back pain on the relationship between the movements of the lumbar spine and hip. Hum Mov Sci. 2004; 23(1):21-34

10. Boyas S, Hajj M, Bilodeau M. Influence of ankle plantar flexor fatigue on postural sway, lower limb articular angles, and postural strategies during unipedal quiet standing. Gait Posture. 2013;37(4):547-51.

11. Granacher U, Lacroix A, Muehlbauer T et al. Effects of core instability strength training on trunk muscle strength, spinal mobility, dynamic balance and functional mobility in older adults. Gerontology. 2013; 59(2):105-13.

12. Radebold A, Cholewicki J, Polzhofer GK et al. Impaired postural control of the lumbar spine is associated with delayed muscle response times in patients with chronic idiopathic low back pain. Spine. 2001;26(7):72430.

13. Kim JH, Park SK, Kang JI et al. Effects of Lumbar Stability Exercise Program on Trunk, Lower Extremity of Muscle Activity and Balance in Soccer Player. J Kor Soc Phys Ther. 2010;22(5):25-31.

14. Nadler SF, Malanga GA, Bartoli LA et al. Hip muscle imbalance and low back pain in athletes: Influence of core strengthening. Med Sci Sports Exerc. 2002;34(1):9-16.

15. Lee KJ, Kim SH, Song CH. Balance exercise program using training mats improves the postural balance of elderly individuals: a Random- ized controlled trial. J Kor Soc Phys Ther. 2012;24(3):223-8

16. Johanson E, Brumagne $S$, Janssens L et al. The effect of acute back muscle fatigue on postural control strategy in people with and without recurrent low back pain. Eur Spine J. 2011;20(12):2152-9.

17. Bunn EA, Grindstaff T, Hart JM et al. Effects of paraspinal fatigue on lower extremity motoneuron excitability in individuals with a history of low back pain. J Electromyogr Kinesiol. 2011;21(3):466-70.

18. Jacobs C, UhlTL, Seeley M et al. Strength and fatigability of the dominant and nondominant hip abductors. J Athl Train. 2005;40(3):203-6.

19. Hodges PW, Richardson CA. Contraction of the abdominal muscles associated with movement of the lower limb. Physical Therapy. 1997;77: 132-42.

20. Davarian S, Maroufi N, Ebrahimi I et al. Trunk muscles strength and endurance in chronic low back pain patients with and without clinical instability.J Back Musculoskelet Rehabil. 2012;25(2):123-9.

21. Mazaheri M, Coenen P, Parnianpour M. Low back pain and postural sway during quiet standing with and without sensory manipulation: a systematic review. Gait Posture. 2013;37(1):12-22.

22. Brown CN, Mynark R. Balance deficits in recreational athletes with chronic ankle instability. J Athl Train. 2007;42(3):367-73.

23. Hicks GE. Invited commentary on "low interrater reliability of examiners performing the proneinstabilitytest: a clinical test for lumbar shear instability". Arch Phys Med Rehabil. 2011;92(6):920-2.

24. Süüden E, Ereline J, Gapeyeva $\mathrm{H}$ et al. Low back muscle fatigue during Sørensen endurance test in patients with chronic low back pain: relationship between electromyographic spectral compression and anthropometric characteristics. Electromyogr Clin Neurophysiol. 2008;48(34):185-92.

25. Fullam K, Caulfield B, Coughlan GF et al. Kinematic analysis of selected reach directions of the star excursion balance test compared to the Ybalance test. J Sport Rehabil. 2013;23(1):27-35.

26. Ahn CS, Kim HS, Kim MC. The effect of the EMG activity of the lower leg with dynamic balance of the recreational athletes with functional ankle instability. J PhysTher Sci. 2011;23(4):579-83.

27. Chang KM, Liu SH, Wu XH. A wireless sEMG recording system and its application to muscle fatigue detection. Sensors (Basel). 2012;12(1):48999.

28. Hong SM, Kweon MJ, Park JW. A study on EMG activation changes of spinal stability muscles during forced respiratory maneuvers. J Kor SocPhys Ther. 2013;26(2):62-7.

29. Kang YH. Effects of Nordic Walking on Tibialis Anterior Muscle Fatigue. J KorSocPhysTher. 2014;26(2):62-7.

30. Lee WJ, Park S, Park JW. Influence of trunk stabilization exercise upon the lumbar stabilization and foot pressure in patients with back pain. J Kor Soc Phys Ther. 2012;24(3):186-90.

31. Dickin DC, Doan JB. Postural stability in altered and unaltered sensory environments following fatiguing exercise of lower extremity joints. Scand J Med Sci Sports. 2008;18(6):765-72.

32. Johanson E, Brumagne S, Janssens L et al. The effect of acute back muscle fatigue on postural controlstrategy in people with and without recurrent low back pain. Eur Spine J. 2011;20:2152-9.

33. Madigan ML, Davidson BS, Nussbaum MA. Postural sway and joint kinematics during quiet standing are affected by lumbar extensorfatigue. Hum Mov Sci. 2006;25(6):788-99. 
34. Kankaanpää M, Taimela S, Laaksonen D et al. Back and hip extensor fatigability in chronic low back pain patients and controls. Arch Phys Med Rehabil. 1998;79(4):412-17.

35. Ebenbichler GR, Oddsson LI, Kollmitzer J et al. Sensory-motor control of the lower back: implications for rehabilitation. Med Sci Sports Exerc. 2001;33(11):1889-98.

36. Lee DC, Sung PS, Yoon B. Lumbar spine stability for subjects with and without low back pain during one leg standing test. Spine. 2010;35(16): 753-60.
37. Chang JS, Lee HY, Lee MY. The study of lumbar erector spinea and rectus abdominis activations according to the different gait velocities in young healthy adults. J Kor Soc Phys Ther. 2012;24(3):186-90.

38. Kim BK, Lee MH, Kim GC. Comparison of abdominal muscle activity during exercises using a sling and swiss-ball. J Kor Soc Phys Ther. 2013; 25(3):149-54.

39. Panjabi MM. Clinical spinal instability and low back pain. J Electromyogr Kinesiol. 2003;13(4):371-9. 